\title{
Association between estrogen receptor $\beta$ polymorphisms and prostate cancer in a Slovak population
}

\author{
JANA JUREČEKOVÁ ${ }^{1}$, MONIKA KMEŤOVÁ SIVOŇOVÁ ${ }^{1}$, HENRIETA DROBKOVÁ ${ }^{2}$, \\ MÁRK HÍVEŠ ${ }^{1}$, DANIEL EVIN ${ }^{1,3}$, JÁN KLIMENT ${ }^{4}$ and DUŠAN DOBROTA ${ }^{1}$ \\ ${ }^{1}$ Department of Medical Biochemistry, Jessenius Faculty of Medicine in Martin, Comenius University in Bratislava; \\ ${ }^{2}$ Biomedical Center Martin, Jessenius Faculty of Medicine in Martin, Comenius University in Bratislava; \\ ${ }^{3}$ Clinic of Nuclear Medicine, Jessenius Faculty of Medicine in Martin and University Hospital Martin, \\ Comenius University in Bratislava; ${ }^{4}$ Clinic of Urology, Jessenius Faculty of Medicine in Martin and \\ University Hospital Martin, Comenius University in Bratislava, 03601 Martin, Slovakia
}

Received May 27, 2020; Accepted December 14, 2020

DOI: 10.3892/ol.2021.12475

\begin{abstract}
Sex steroid hormones have important roles in the function of the prostate; however, they may also serve as factors in the initiation and progression of carcinogenesis. Estrogens, acting through estrogen receptors, may significantly affect prostate cancer development and progression. The main aim of the present study was to analyze the association between the rs3020449, rs4986938 and rs1256049 polymorphisms in the promoter region of the estrogen receptor $\beta$ (ESR2) gene and prostate cancer risk in the Slovak population. A total of 510 patients with prostate cancer and 184 healthy men were included in the present study. No association between the rs4986938 and rs1256049 polymorphisms and prostate cancer development and progression was revealed; however, there was a statistically significant association between the rs3020449 GG genotype [odds ratio (OR), 2.35; $\mathrm{P}=0.002$ ] and the $\mathrm{G}$ allele $(\mathrm{OR}, 1.42 ; \mathrm{P}=0.005)$ and a higher risk of prostate cancer development. The rs3020449 GG genotype was significantly associated with a higher risk of development of carcinoma with a Gleason score $>7(\mathrm{OR}, 2.66 ; \mathrm{P}=0.005)$, as well as with the development of carcinoma with pT3/pT4 $(\mathrm{OR}, 2.28 ; \mathrm{P}=0.02)$. According to the results from the present study, the rs3020449 polymorphism, in the promoter region of ESR2, may be considered to have a role in the development and progression of prostate cancer in the Slovak population.
\end{abstract}

Correspondence to: Dr Jana Jurečeková, Department of Medical Biochemistry, Jessenius Faculty of Medicine in Martin, Comenius University in Bratislava, Malá Hora 4D, 03601 Martin, Slovakia E-mail: jurecekova1@uniba.sk

Key words: prostate cancer, estrogen receptor $\beta$, rs3020449, rs4986938, rs1256049

\section{Introduction}

Prostate cancer is the third most common oncological disease in men, according to the incidence and mortality rates in Slovakia (1). Endogenous sex steroid hormones, along with environmental and dietary factors, and immune and inflammatory responses are involved in the pathogenesis of prostate cancer (2). Prostate cancer is an androgen-dependent tumor, which notably increases with age. However, there is consistent evidence that both total and bioavailable serum testosterone levels significantly decline with age (3). Circulating testosterone levels decline with age at a greater extent compared with that in circulating estradiol, resulting in an elevated ratio of estradiol to testosterone. The increased ratio might also indirectly reflect aromatase activity and a higher conversion of testosterone to estradiol at an older age (4). Estrogens play an important role in male sex hormone secretion, in the growth, differentiation and homeostasis of normal prostate tissue as well as in prostate carcinogenesis (5). Epidemiological studies have not confirmed the direct association between serum estrogen levels and prostate cancer risk (6-8), there is a possibility that intraprostatic estrogen milieu may play a more important role than circulating estrogen levels.

Estrogen action is commonly mediated by two receptors, estrogen receptor $\alpha(\mathrm{ER} \alpha)$ and estrogen receptor $\beta(\mathrm{ER} \beta)$, which are encoded by separate genes (ESR1 and ESR2, respectively). Both receptors belong to nuclear receptors, acting as ligand-activated transcription factors. $\mathrm{ER} \alpha$ and $\mathrm{ER} \beta$ share high sequence homology, particularly in a DNA-binding domain, allowing both receptors to recognize the estrogen-responsive element on the DNA. Lower sequence homology has been described in the ligand-binding domain, suggesting that both receptors may have different specific ligands (9). Estrogen receptors activated by their ligands, act through two signaling mechanisms. The main mechanism includes diffusion of estrogens across the cell membrane and their binding to estrogen receptors. The receptors then dimerize and bind to estrogen responsible element sequences in the promoter region of the target genes and such affect gene transcription. The second mechanism is mediated 
by membrane-localized estrogen receptors. The binding of steroid ligands leads to rapid signaling mediated by $\mathrm{G}$ protein activation. This includes the generation of cyclic nucleotides (cAMP and cGMP) and calcium efflux, which activates kinase cascades (10).

The exact role of estrogen receptors in prostate carcinogenesis requires further elucidation. It is hypothesized that the two types of estrogen receptors have different roles in prostate cancer. ER $\alpha$ is proposed to contribute to cellular proliferation, inflammation and has been found to be upregulated in malignant epithelial prostate tissue (11), while ER $\beta$ exhibits antiproliferative, anti-invasive and proapoptotic effects $(12,13)$, and its expression declines during the development of prostate cancer (14).

The ESR2 gene, encoding ER $\beta$, is located on chromosome $14 \mathrm{q} 23.1$ (15) and is expressed in both stromal and epithelial cells of the prostate. The loss of ESR 2 expression may be considered as a risk factor for prostate cancer (16). The precise mechanism of how ESR2 is regulated in prostate cancer cells is still unknown. Decreased ESR 2 expression may be caused by the methylation of $\mathrm{CpG}$ islands, located in the promoter region (17). The presence of polymorphisms in the coding regions of the gene may also affect gene expression levels or transcript stability. Among the most extensively studied polymorphisms in the ESR2 gene are rs1256049 and rs4986938; however, the functional significance of both polymorphisms is still unknown. The rs1256049 is a synonymous variant located within the ligand binding domain in exon 5 (18). Meta-analysis has shown significant association between rs1256049 and prostate cancer in Caucasians, but not in overall population (19). The second polymorphism, rs4986938 represents a $\mathrm{G}>\mathrm{A}$ transition in the 3 '-untranslated region of exon 8 (20). It is hypothesized that the untranslated regions of genes are regulatory elements, controlling translation and may be a target for microRNAs (21). Numerous studies have investigated the association between the rs4986938 polymorphism and different types of cancer; it was found to be associated with breast $(22,23)$ and prostate cancers $(24)$. However, a meta-analysis conducted to investigate the association of rs4986938 and the overall risk of cancer found no significant associations (25). The polymorphism rs3020449 is located near the transcription start site of the promoter $0 \mathrm{~N}$ of the ESR2 gene. It is hypothesized that polymorphisms located in the promoter region could affect transcription factor binding and affect gene transcription (26). The association between rs3020449 and prostate cancer has not been investigated; however, it was found to be associated with other oncological diseases, such as endometrial (27), ovarian (28) and breast cancers (29).

The aim of the present study was to determine the ESR2 expression levels in hyperplastic and malignant prostate tissues and analyze the possible association of three polymorphisms in the ESR2 gene (rs3020449, rs4986938 and rs1256049) with prostate cancer development and progression.

\section{Materials and methods}

Study population. The case-control study included 510 patients with histologically verified prostate cancer and 184 healthy men. Tissue samples from 22 patients with prostate cancer and 12 patients with benign prostatic hyperplasia (BHP) were collected during routine surgery, placed into RNA stabilization solution and stored at $-80^{\circ} \mathrm{C}$ until further analysis. All patients were recruited at the Department of Urology, University Hospital Martin in Slovakia, between 2005 and 2019. Healthy volunteers were selected from men attending routine urological examination and were confirmed to have no history of cancer or any prostate disease. The present study was approved by the Ethics Committee of Comenius University in Bratislava, Jessenius Faculty of Medicine in Martin and all men provided written informed consent to participate in the study. The clinical characteristics of the study groups are summarized in Table I.

Genotyping. Genomic DNA samples from the individuals were isolated from whole blood using The Wizard ${ }^{\circledR}$ Genomic DNA Purification kit (Promega Corporation) according to the manufacturer's protocol and stored at $-20^{\circ} \mathrm{C}$ until further analysis. The ESR 2 gene polymorphism, rs3020449 was analyzed using tetra-primer amplification refractory mutation system PCR approach (30) allowing allele-specific amplification using the following primers: IP1, 5'-GCATTGTCCTTT TTACATATTGTTAGGGTA-3'; IP2, 5'-AATTCTCAAGGA AATTTTAGCAAAGCC-3'; OP1, 5'-TAGATTTTGTCAAAC ACTTTTGGTGGAT-3'; OP2, 5'-CCAAATGATTAAGGA GAAATAACAGCAG-3'. The PCR Master mix contained 100 ng genomic DNA, $2.4 \mu 1$ 5X HOT FIREPol ${ }^{\circledR}$ Blend Master Mix RTL (Solis BioDyne OÜ), $0.5 \mu \mathrm{l}$ each primer and $6.6 \mu \mathrm{l}$ nuclease-free water. The following thermocycling conditions were used: Initial denaturation at $95^{\circ} \mathrm{C}$ for $15 \mathrm{~min}$ followed by 35 cycles at $95^{\circ} \mathrm{C}$ for $20 \mathrm{sec}, 56^{\circ} \mathrm{C}$ for $50 \mathrm{sec}$ and $72^{\circ} \mathrm{C}$ for $1 \mathrm{~min}$, with a final extension at $72^{\circ} \mathrm{C}$ for $5 \mathrm{~min}$. The PCR products were separated using $2 \%$ agarose gel electrophoresis. The allele-specific product size for rs3020449 was 231 or $193 \mathrm{bp}$ for the $A$ and $G$ alleles, respectively).

The ESR2 gene polymorphisms, rs4986938 and rs1256049 were determined using the PCR-restriction fragment length polymorphism method and the following primers: rs4986938 forward, 5'-GACCTGCTGCTGGAGATGCT-3' and reverse, 5'-AATGAGGGACCACACAGCA-3'; and rs1256049 forward, 5'-TCTTGCTTTCCCCAGGCTTT-3' and reverse, 5'-ACCTGT CCAGAACAAGATCT-3'. The PCR Master mix contained 100 ng genomic DNA, $6 \mu 1$ Dream Taq Green PCR master mix (2X) (Thermo Fisher Scientific Inc.), $30 \mathrm{ng}$ forward and reverse primers and nuclease-free water to a total volume of $12 \mu \mathrm{l}$. The following thermocycling conditions were used: Initial denaturation at $95 \mathrm{C}$ for $5 \mathrm{~min}$ followed by 35 cycles at $95^{\circ} \mathrm{C}$ for $20 \mathrm{sec}$, $58^{\circ} \mathrm{C}$ for $50 \mathrm{sec}$ for rs 4986938 or $56^{\circ} \mathrm{C}$ for $50 \mathrm{sec}$ for rs 1256049 , and $72^{\circ} \mathrm{C}$ for $1 \mathrm{~min}$, with a final extension at $72^{\circ} \mathrm{C}$ for $5 \mathrm{~min}$. The PCR products of the rs4986938 polymorphism were digested with $A l u \mathrm{I}$, which produced a $234 \mathrm{bp}$ sized band for the GG genotype; 168 and 66 bp sized bands for the AA genotype and 234, 168 and 66 bp sized bands for the GA genotype. The PCR products of the rs1256049 polymorphism were digested with $R s a \mathrm{I}$, which produced a 156 bp sized band for the GG genotype; 110 and 46 bp sized bands for the AA genotype and 156, 110 and $46 \mathrm{bp}$ sized bands for the GA genotype.

Gene expression analysis. Isolation of total RNA was performed using an AllPrep DNA/RNA/miRNA Universal kit (Qiagen $\mathrm{GmbH}$ ) according to the manufacturer's protocol. For each sample, an equal quantity of RNA ( $1 \mu \mathrm{g})$ was used for reverse transcription into cDNA with a RT2 First Strand kit, following the standard protocol (Qiagen $\mathrm{GmbH}$ ). Reverse transcription-quantitative 
Table I. Characteristics of patients with prostate cancer and healthy subjects.

\begin{tabular}{lcr}
\hline Characteristics & Healthy controls $(\mathrm{n}=184)$ & Prostate cancer $(\mathrm{n}=510)$ \\
\hline Age, years & & $67 \pm 8.26$ \\
Mean \pm SD & $57.61 \pm 10.39$ & $10.57(5.84-28.76)$ \\
PSA, ng/ml & & \\
Median (25-75th percentile) & $0.81(0.49-1.60)$ & 270 \\
Gleason score & & 136 \\
$\leq 7$ & NA & $7.28 \pm 1.25$ \\
$>7$ & NA & 104 \\
Mean \pm SD & NA & \\
Missing & NA & \\
Pathological stage & & 88 \\
pT1/pT2 & NA & 148 \\
pT3/pT4 & NA & 274 \\
Missing & NA &
\end{tabular}

NA, not applicable.

PCR analysis of the ESR2 expression level was performed using Custom $\mathrm{RT}^{2}$ Profiler PCR array (Qiagen $\mathrm{GmbH}$ ). GAPDH and actin served as housekeeping genes.

Statistical analysis. Genotype frequencies were calculated for the patients with prostate cancer and the healthy controls. Observed genotype frequencies were tested for Hardy-Weinberg equilibrium in the control group. Dominant, codominant and recessive genetic models were evaluated. The comparison of the genotype distribution and association with selected clinical data was performed using a Fisher's exact test. Fisher's exact test, calculation of odds ratios and 95\% confidence intervals (CIs) were performed using the StatsDirect statistical package (v2.7.0.2). The test for linkage disequilibrium of the selected polymorphisms was performed using Haploview 4.2 software.

The relative quantification method was used for the analysis of ESR2 expression levels. The $\mathrm{C}_{\mathrm{q}}$ values of the ESR2 gene were compared with the average $\mathrm{C}_{\mathrm{q}}$ values of the two housekeeping genes to obtain $\Delta \mathrm{C}_{\mathrm{q}}$ values. The fold-change was calculated as $2^{-\Delta \Delta \mathrm{Cq}}(31)$. The data are represented in the figures as median \pm IQR. The Mann-Whitney test was used for the comparison of the ESR2 mRNA expression levels between patients with prostate cancer and with BHP. The Mann-Whitney test with Bonferroni correction was used for the comparison of the ESR2 mRNA expression levels between rs3020449 genotypes. All P-values were derived from two-sided tests and $\mathrm{P}<0.05$ was considered to indicate a statistically significant difference. Statistical analysis was performed using the StatsDirect statistical package (v2.7.0.2).

\section{Results}

Genotype analysis. The genotype frequencies of the three analyzed $E S R 2$ variants did not deviate from the Hardy-Weinberg equilibrium and their genotyping success rates were over $95 \%$. The analyzed polymorphisms were not found to be in linkage disequilibrium, while the estimated $\mathrm{R}^{2}$ values were $0.02,0.02$ and 0.12 , respectively (Fig. 1). The distribution of the genotypes and alleles of the three analyzed ESR 2 polymorphisms in both the control group and in the patients with prostate cancer are summarized in Table II. Dominant, codominant and recessive genetic models were evaluated.

There was a statistically significant association between the rs3020449 GG genotype [odds ratio (OR), 2.35; 95\% CI 1.31-4.36; $\mathrm{P}=0.002]$ compared with that in the AA genotype, as well as in the recessive model (OR, 2.20; 95\% CI 1.23-3.92; $\mathrm{P}=0.002)$ and the higher risk of prostate cancer development. The frequency of the rs3020449 $\mathrm{G}$ allele (OR, 1.42; 95\% CI $1.10-1.84 ; \mathrm{P}=0.005$ ) was also significantly higher in the patients with prostate cancer (Table II). The other two analyzed ESR2 variants, rs4986938 and rs1256049, were not found to be associated with the risk of prostate cancer development.

To detect the possible associations between the ESR2 polymorphisms and the selected clinical features, patients were stratified according to Gleason score ( $\leq 7$ and $>7)$, pathological T stage (pT1/pT2 and pT3/pT4) and prostate-specific antigen levels $(<10$ and $\geq 10 \mathrm{ng} / \mathrm{ml})$. There was a statistically significant association between the rs3020449 GG genotype and a higher risk of development of carcinoma with a Gleason score $\leq 7$ (OR, 1.97; 95\% CI 1.09-3.86; $\mathrm{P}=0.029)$; however, a more significant association was observed in patients with Gleason score $>7$ (OR, 2.66; 95\% CI 1.27-5.64; $\mathrm{P}=0.005)$. The rs3020449 $\mathrm{G}$ allele was significantly associated with development of carcinoma with a Gleason score $>7(\mathrm{OR}, 1.53$; $95 \% \mathrm{CI}$ 1.09-2.13; $\mathrm{P}=0.01$ ) (Table III).

After stratification of the patients with prostate cancer according to pathological $\mathrm{T}$ stage, a significant association between the rs3020449 GG genotype (OR, 2.28; 95\% CI $1.10-4.76 ; \mathrm{P}=0.02)$, as well as with the $\mathrm{G}$ allele (OR, 1.39; 95\% CI 1.00-1.93; $\mathrm{P}=0.04$ ) and the development of carcinoma with pT3/pT4 was detected. In the group of patients with $\mathrm{pT} 1 / \mathrm{pT} 2$, there was no significant association with increased risk. The results are summarized in Table IV. The rs3020449 


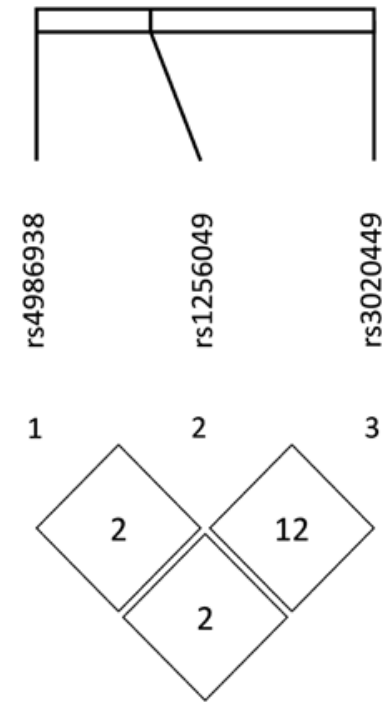

Figure 1. $\mathrm{R}^{2}$ plot of analyzed $E S R 2$ gene variants estimated by Haploview 4.2 . $E S R 2$, estrogen receptor $\beta$. The analyzed polymorphisms were not found to be in linkage disequilibrium, according to the estimated $\mathrm{R}^{2}$ values.

GG genotype was significantly associated with a higher risk of prostate cancer development in both groups of patients with PSA $<10 \mathrm{ng} / \mathrm{ml}(\mathrm{OR}, 2.24 ; 95 \%$ CI 1.19-4.26; $\mathrm{P}=0.01)$, as well as with $\mathrm{PSA} \geq 10 \mathrm{ng} / \mathrm{ml}(\mathrm{OR}, 2.10 ; 95 \%$ CI $1.12-4.00 ; \mathrm{P}=0.02)$ (Table V). There was no association between the rs 4986938 and rs1256049 variants and Gleason score, pathological T stage and PSA levels in patients with prostate cancer (Tables III-V).

Expression levels of ESR $2 \mathrm{mRNA}$. The relative ESR2 mRNA expression levels were found to be significantly higher in BHP tissues compared with that in prostate cancer tissues $(\mathrm{P}=0.002)$ (Fig. 2). It was found that $E S R 2$ mRNA expression levels were 5.47-fold higher in BHP tissues compared with that in prostate cancer tissues. Analysis of relative ESR2 mRNA expression levels in patients with prostate cancer with different rs3020449 genotypes revealed that the rs3020449 GG genotype had 3.38-fold lower ESR2 expression levels compared with that in patients with the AA genotype ( $\mathrm{P}=0.04)$ (Fig. 3); however the result was not statistically significant after Bonferroni correction for multiple comparisons.

\section{Discussion}

Prostate cancer is a heterogenous disease, with numerous factors contributing to its development and progression. The prostate is a hormone-dependent tissue, and estrogens are the targets of research. The aim of the present study was to evaluate the association between three ESR2 polymorphisms and the increased risk of prostate cancer, and to determine the relative ESR2 mRNA expression levels in hyperplastic and malignant prostate tissues. There was only a limited number of tissue samples; however, significantly higher relative ESR2 mRNA expression levels were found in BHP tissues compared with that in prostate cancer tissues. Several publications have reported the decrease or loss of ER $\beta$ protein expression during prostate cancer progression using immunohistochemical staining $(32,33)$. Latil et al $(34)$ also reported a decrease in ER $\beta$ mRNA expression levels in

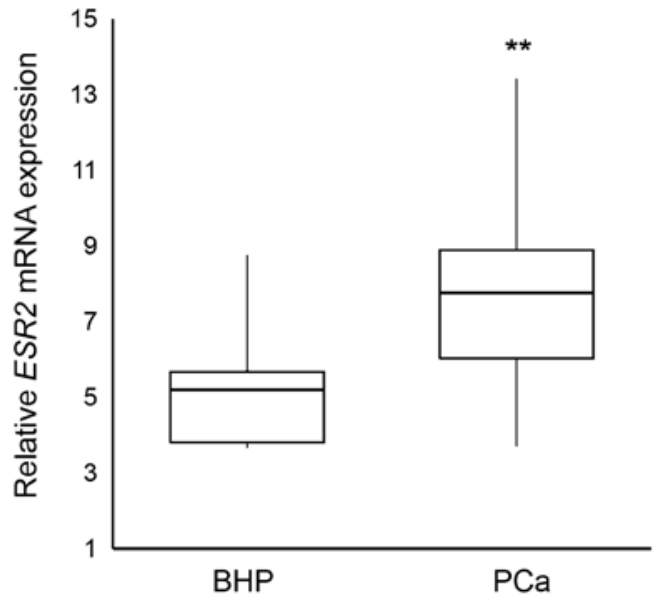

Figure 2. Relative ESR2 mRNA expression levels in patients with BHP and prostate cancer. The boxes define the first quartile, median and trird quartile values. The lines define minimum and maximum values. Mann-Whitney test was used for the comparison between groups. ${ }^{* *} \mathrm{P}<0.01$. BHP, benign prostatic hyperplasia; PCa, prostate cancer; ESR2, estrogen receptor $\beta$.

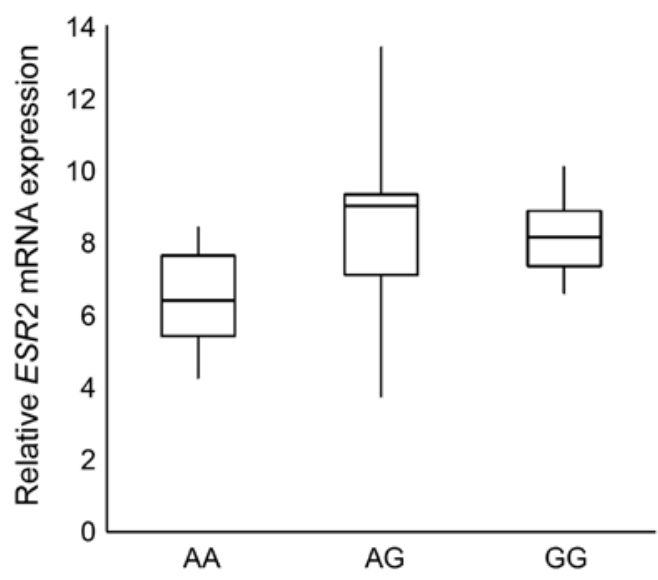

Figure 3. Relative ESR2 mRNA expression levels in patients with prostate cancer with the different rs3020449 genotypes. The boxes define the first quartile, median and trird quartile values. The lines define minimum and maximum values. ESR2, estrogen receptor $\beta$.

the majority of prostate tumors compared to that in normal tissue. Pasquali et al (35) described that the loss of the ER $\beta$ protein may promote cell proliferation and possibly carcinogenesis. On the other hand, some reports also suggest a negative role of ER $\beta$ protein expression levels in prostate cancer prognosis $(36,37)$. Grindstad et al $(38)$ found that the ER $\beta$ protein expression levels were associated with reduced time to biochemical failure. Opposing observations obtained by different research groups might be partially explained by the existence of different ER $\beta$ isoforms. The wild-type ER $\beta 1$ inhibits proliferation, has tumor-suppressing effects and is lost during prostate cancer progression. Its splice variant, $\mathrm{ER} \beta 2$, increases proliferation, therefore is oncogenic and is expressed in advanced prostate cancer (39).

One of the factors with the potential to affect the expression levels of the ESR2 gene are single nucleotide polymorphisms. In the present study, there was no association between the rs 4986938 and rs 1256049 polymorphisms and the risk of prostate cancer development and progression. 
Table II. Distribution of the ESR2 genotypes and alleles and their association with the risk of prostate cancer.

Controls vs. Prostate cancer

Genotype Healthy controls, $\mathrm{n}$

Prostate cancer, $\mathrm{n}$

OR $(95 \% \mathrm{CI}) \quad$ P-value

ESR2 rs3020449

Codominant model

AA 75

AG 90

173

234

GG

19

103

1.00 (ref.)

Dominant model

AA

173

$\mathrm{AG}+\mathrm{GG}$

109

337

165

407

$\mathrm{AA}+\mathrm{AG}$

19

103

$1.13(0.77-1.65)$

0.58

2.35 (1.31-4.36)

$0.002^{\mathrm{a}}$

GG

240

580

440

1.00 (ref.)

1.34 (0.93-1.92)

0.11

A

128

1.00 (ref.)

$2.20(1.29-3.92)$

$0.002^{\mathrm{a}}$

G

1.00 (ref.)

1.42 (1.10-1.84)

$0.005^{\mathrm{a}}$

ESR2 rs1256049

Codominant model

GG

166

460

1.00 (ref.)

GA

18

47

0.94 (0.52-1.78)

0.88

AA

0

NA

NA

Dominant model

GG

166

460

1.00 (ref.)

$\mathrm{GA}+\mathrm{AA}$

18

50

$1.00(0.56-1.88)$

1.00

Allele

G

350

967

1.00 (ref.)

A

18

53

1.07 (0.60-1.96)

0.89

ESR2 rs4986938

Codominant model

GG

GA

AA

Dominant model

GG

$\mathrm{GA}+\mathrm{AA}$

Recessive model

GG + GA

AA

Allele

G

A
88

77

19

88

96

165

19

253

115
228

229

49

228

278

457

49

685

327
1.00 (ref.)

$1.15(0.79-1.67)$

0.47

$1.00(0.54-1.89)$

$>0.99$

1.00 (ref.)

$1.12(0.79-1.59)$

0.55

1.00 (ref.)

$0.93(0.52-1.73)$

0.77

1.00 (ref.)

1.05 (0.81-1.37)
0.74

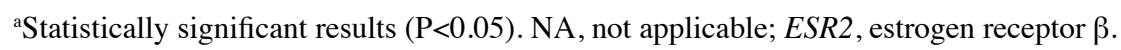

The majority of published studies have also not confirmed an association between the rs4986938 and rs1256049 polymorphisms in the Caucasian population (40-44) or in mixed populations (45-47) and prostate cancer risk. On contrary, there are some studies that have described a significant association between the rs4986938 and rs1256049 polymorphisms and increased risk of prostate cancer development in
Iranian (48) and Caucasian populations (49). On the other hand, a Japanese study discovered that both the rs4986938 and rs1256049 polymorphisms were significantly associated with a decreased risk of prostate cancer (24). As a result of the conflicting results of the published studies, Li et al (25) conducted a meta-analysis, in which they found no evidence of an association between the rs4986938 polymorphism and 
Table III. Association between the ESR2 genotypes and alleles and Gleason score in prostate cancer patients.

\begin{tabular}{|c|c|c|c|c|c|c|}
\hline \multirow[b]{2}{*}{ Genotype } & \multicolumn{3}{|c|}{ Gleason score $\leq 7$} & \multicolumn{3}{|c|}{ Gleason score $>7$} \\
\hline & $\mathrm{n}$ & OR $(95 \% \mathrm{CI})$ & P-value & $\mathrm{n}$ & OR $(95 \% \mathrm{CI})$ & P-value \\
\hline \multicolumn{7}{|c|}{ ESR2 rs3020449 } \\
\hline \multicolumn{7}{|c|}{ Codominant model } \\
\hline AA & 100 & 1.00 (ref.) & & 43 & 1.00 (ref.) & \\
\hline $\mathrm{AG}$ & 120 & $1.00(0.65-1.53)$ & 1.00 & 64 & $1.24(0.74-2.10)$ & 0.45 \\
\hline GG & 50 & $1.97(1.04-3.84)$ & $0.029^{\mathrm{a}}$ & 29 & $2.66(1.27-5.64)$ & $0.005^{\mathrm{a}}$ \\
\hline \multicolumn{7}{|c|}{ Dominant model } \\
\hline AA & 100 & 1.00 (ref.) & & 43 & & \\
\hline $\mathrm{AG}+\mathrm{GG}$ & 170 & $1.17(0.78-1.75)$ & 0.43 & 93 & $1.49(0.91-2.44)$ & 0.10 \\
\hline \multicolumn{7}{|c|}{ Recessive model } \\
\hline $\mathrm{AA}+\mathrm{AG}$ & 220 & 1.00 (ref.) & & 107 & 1.00 (ref.) & \\
\hline GG & 50 & $1.97(1.09-3.68)$ & $0.02^{\mathrm{a}}$ & 29 & $2.35(1.20-4.67)$ & $0.007^{\mathrm{a}}$ \\
\hline \multicolumn{7}{|l|}{ Allele } \\
\hline $\mathrm{A}$ & 320 & 1.00 (ref.) & & 150 & 1.00 (ref.) & \\
\hline $\mathrm{G}$ & 220 & $1.29(0.97-1.71)$ & 0.07 & 122 & $1.53(1.09-2.13)$ & $0.01^{\mathrm{a}}$ \\
\hline \multicolumn{7}{|c|}{ ESR2 rs1256049 } \\
\hline \multicolumn{7}{|c|}{ Codominant model } \\
\hline GG & 242 & 1.00 (ref.) & & 122 & 1.00 (ref.) & \\
\hline GA & 28 & $1.06(0.55-2.12)$ & 0.88 & 11 & $0.83(0.34-1.94)$ & 0.70 \\
\hline AA & 0 & NA & NA & 3 & NA & NA \\
\hline \multicolumn{7}{|c|}{ Dominant model } \\
\hline GG & 242 & 1.00 (ref.) & & 122 & 1.00 (ref.) & \\
\hline $\mathrm{GA}+\mathrm{AA}$ & 28 & $1.06(0.55-2.12)$ & 0.88 & 14 & $1.05(0.47-2.35)$ & 1.00 \\
\hline \multicolumn{7}{|l|}{ Allele } \\
\hline G & 512 & 1.00 (ref.) & & 255 & 1.00 (ref.) & \\
\hline A & 28 & $1.06(0.56-2.07)$ & 0.88 & 17 & $1.30(0.61-2.72)$ & 0.49 \\
\hline \multicolumn{7}{|c|}{ ESR2 rs4986938 } \\
\hline \multicolumn{7}{|c|}{ Codominant model } \\
\hline GG & 118 & 1.00 (ref.) & & 66 & 1.00 (ref.) & \\
\hline GA & 125 & $1.21(0.80-1.83)$ & 0.36 & 54 & $0.93(0.57-1.54)$ & 0.81 \\
\hline $\mathrm{AA}$ & 26 & $1.02(0.51-2.08)$ & 1.00 & 13 & $0.91(0.38-2.11)$ & 0.85 \\
\hline \multicolumn{7}{|c|}{ Dominant model } \\
\hline GG & 118 & 1.00 (ref.) & & 66 & 1.00 (ref.) & \\
\hline $\mathrm{GA}+\mathrm{AA}$ & 151 & $1.17(0.79-1.74)$ & 0.44 & 67 & $0.93(0.58-1.49)$ & 0.82 \\
\hline \multicolumn{7}{|c|}{ Recessive model } \\
\hline $\mathrm{GG}+\mathrm{GA}$ & 243 & 1.00 (ref.) & & 120 & 1.00 (ref.) & \\
\hline AA & 26 & $0.93(0.48-1.84)$ & 0.87 & 13 & $0.94(0.41-2.10)$ & 1.00 \\
\hline \multicolumn{7}{|l|}{ Allele } \\
\hline G & 361 & 1.00 (ref.) & & 186 & 1.00 (ref.) & \\
\hline A & 177 & $1.08(0.80-1.45)$ & 0.61 & 80 & $0.94(0.66-1.35)$ & 0.79 \\
\hline
\end{tabular}

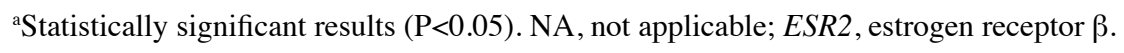

prostate cancer risk, while a meta-analysis into the association between the rs1256049 and prostate cancer revealed a significant association in the Caucasian population, but not in the overall population (19).

The promoter region of the ESR2 gene is complex and has not been fully described; however, it is hypothesized that polymorphisms in this region could affect the binding of enhancers or repressors to regulate gene transcription (50). To the best of our knowledge, this is the first study evaluating the association between the rs3020449 polymorphism and the risk of prostate cancer. A significant association between the rs3020449 polymorphism and a higher risk of prostate cancer development and progression was found. The functional impact of this polymorphism is unknown. Decrease in ESR2 mRNA 
Table IV. Distribution of the ESR2 genotypes and alleles in patients stratified according to the pathological stage.

\begin{tabular}{|c|c|c|c|c|c|c|}
\hline \multirow[b]{2}{*}{ Genotype } & \multicolumn{3}{|c|}{$\mathrm{pT} 1 / \mathrm{pT} 2$} & \multicolumn{3}{|c|}{ pT3/pT4 } \\
\hline & $\mathrm{n}$ & OR (95\% CI) & P-value & $\mathrm{n}$ & OR $(95 \%$ CI $)$ & P-value \\
\hline \multicolumn{7}{|c|}{ ESR2 rs3020449 } \\
\hline \multicolumn{7}{|c|}{ Codominant model } \\
\hline AA & 35 & 1.00 (ref.) & & 52 & 1.00 (ref.) & \\
\hline $\mathrm{AG}$ & 37 & $0.88(0.49-1.59)$ & 0.67 & 66 & $1.06(0.64-1.75)$ & 0.90 \\
\hline GG & 16 & $1.80(0.77-4.20)$ & 0.16 & 30 & $2.28(1.10-4.76)$ & $0.02^{\mathrm{a}}$ \\
\hline \multicolumn{7}{|c|}{ Dominant model } \\
\hline AA & 35 & 1.00 (ref.) & & 52 & 1.00 (ref.) & \\
\hline $\mathrm{AG}+\mathrm{GG}$ & 53 & $1.04(0.60-1.81)$ & 0.90 & 96 & $1.27(0.79-2.04)$ & 0.31 \\
\hline \multicolumn{7}{|c|}{ Recessive model } \\
\hline $\mathrm{AA}+\mathrm{AG}$ & 72 & 1.00 (ref.) & & 118 & 1.00 (ref.) & \\
\hline GG & 16 & $1.93(0.87-4.21)$ & 0.08 & 30 & $2.21(1.14-4.36)$ & $0.01^{\mathrm{a}}$ \\
\hline \multicolumn{7}{|l|}{ Allele } \\
\hline A & 107 & 1.00 (ref.) & & 170 & 1.00 (ref.) & \\
\hline G & 69 & $1.21(0.82-1.78)$ & 0.34 & 126 & $1.39(1.00-1.93)$ & $0.04^{\mathrm{a}}$ \\
\hline \multicolumn{7}{|c|}{ ESR2 rs1256049 } \\
\hline \multicolumn{7}{|c|}{ Codominant model } \\
\hline GG & 82 & 1.00 (ref.) & & 133 & 1.00 (ref.) & \\
\hline GA & 7 & $0.79(0.27-2.08)$ & 0.66 & 15 & $1.04(0.47-2.28)$ & 1.00 \\
\hline AA & 0 & NA & NA & 3 & NA & NA \\
\hline \multicolumn{7}{|c|}{ Dominant model } \\
\hline GG & 82 & 1.00 (ref.) & & 133 & 1.00 (ref.) & \\
\hline $\mathrm{GA}+\mathrm{AA}$ & 7 & $0.79(0.27-2.08)$ & 0.66 & 18 & $1.25(0.59-2.65)$ & 0.60 \\
\hline \multicolumn{7}{|l|}{ Allele } \\
\hline G & 171 & 1.00 (ref.) & & 281 & 1.00 (ref.) & \\
\hline A & 7 & $0.79(0.28-2.05)$ & 0.83 & 21 & $1.45(0.72-2.95)$ & 0.32 \\
\hline \multicolumn{7}{|c|}{ ESR2 rs4986938 } \\
\hline \multicolumn{7}{|c|}{ Codominant model } \\
\hline GG & 40 & 1.00 (ref.) & & 74 & 1.00 (ref.) & \\
\hline GA & 42 & $1.20(0.68-2.11)$ & 0.59 & 57 & $0.83(0.51-1.36)$ & 0.48 \\
\hline AA & 7 & $0.81(0.27-2.22)$ & 0.82 & 16 & $1.00(0.45-2.22)$ & 1.00 \\
\hline \multicolumn{7}{|c|}{ Dominant model } \\
\hline GG & 40 & 1.00 (ref.) & & 74 & 1.00 (ref.) & \\
\hline $\mathrm{GA}+\mathrm{AA}$ & 49 & $1.12(0.66-1.93)$ & 0.70 & 73 & $0.90(0.57-1.42)$ & 0.66 \\
\hline \multicolumn{7}{|c|}{ Recessive model } \\
\hline GG + GA & 82 & 1.00 (ref.) & & 131 & 1.00 (ref.) & \\
\hline AA & 7 & $0.74(0.25-1.94)$ & 0.66 & 16 & $1.06(0.49-2.27)$ & 1.00 \\
\hline \multicolumn{7}{|l|}{ Allele } \\
\hline $\mathrm{G}$ & 122 & 1.00 (ref.) & & 205 & 1.00 (ref.) & \\
\hline A & 56 & $1.01(0.67-1.51)$ & 1.00 & 89 & $0.96(0.68-1.35)$ & 0.80 \\
\hline
\end{tabular}

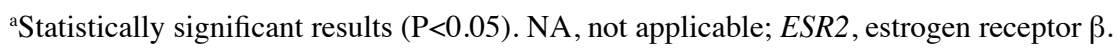

expression levels were found in patients with prostate cancer and the rs3020449 GG genotype compared with that in the AA genotype; however, results were not statistically significant after Bonferroni correction. The potential limitation of presented study is the lack of survival analysis.

There are a limited number of studies that have analyzed the rs3020449 polymorphism with other diseases.
Lattrich et al (27) found that rs3020449 was not associated with the development of endometrial cancer. The polymorphism was also found to be associated with the progression of ovarian cancer, as it was more frequent in patients with FIGO staged III + IV (28). On the other hand, it was not found to be associated with uterine fibroids (51). With respect to breast cancer, some studies have found no association of 
Table V. Distribution of the ESR2 genotypes and alleles in patients stratified according to the PSA levels.

\begin{tabular}{|c|c|c|c|c|c|c|}
\hline \multirow[b]{2}{*}{ Genotype } & \multicolumn{3}{|c|}{$\mathrm{PSA}<10 \mathrm{ng} / \mathrm{ml}$} & \multicolumn{3}{|c|}{$\mathrm{PSA} \geq 10 \mathrm{ng} / \mathrm{ml}$} \\
\hline & $\mathrm{n}$ & OR (95\% CI) & P-value & $\mathrm{n}$ & OR $(95 \% \mathrm{CI})$ & P-value \\
\hline \multicolumn{7}{|c|}{ ESR2 rs3020449 } \\
\hline \multicolumn{7}{|c|}{ Codominant model } \\
\hline AA & 74 & 1.00 (ref.) & & 77 & 1.00 (ref.) & \\
\hline AG & 91 & $1.02(0.66-1.58)$ & 0.91 & 104 & $1.13(0.73-1.72)$ & 0.59 \\
\hline GG & 42 & $2.24(1.19-4.26)$ & $0.01^{\mathrm{a}}$ & 41 & $2.10(1.12-4.00)$ & $0.02^{\mathrm{a}}$ \\
\hline \multicolumn{7}{|c|}{ Dominant model } \\
\hline $\mathrm{AA}$ & 74 & 1.00 (ref.) & & 77 & 1.00 (ref.) & \\
\hline $\mathrm{AG}+\mathrm{GG}$ & 133 & $1.24(0.82-1.90)$ & 0.31 & 145 & $1.30(0.86-1.94)$ & 0.21 \\
\hline \multicolumn{7}{|c|}{ Recessive model } \\
\hline $\mathrm{AA}+\mathrm{AG}$ & 165 & 1.00 (ref.) & & 181 & 1.00 (ref.) & \\
\hline GG & 42 & $2.21(1.24-4.03)$ & $0.007^{\mathrm{a}}$ & 41 & $1.97(1.10-3.58$ & $0.02^{\mathrm{a}}$ \\
\hline \multicolumn{7}{|l|}{ Allele } \\
\hline A & 239 & 1.00 (ref.) & & 258 & 1.00 (ref.) & \\
\hline $\mathrm{G}$ & 175 & $1.37(1.03-1.84)$ & $0.03^{\mathrm{a}}$ & 186 & $1.35(1.02-1.80)$ & $0.04^{\mathrm{a}}$ \\
\hline \multicolumn{7}{|c|}{ ESR2 rs1256049 } \\
\hline \multicolumn{7}{|c|}{ Codominant model } \\
\hline GG & 186 & 1.00 (ref.) & & 198 & 1.00 (ref.) & \\
\hline GA & 21 & $1.04(0.53-2.05)$ & 0.91 & 21 & $0.98(0.50-1.92)$ & 0.95 \\
\hline AA & 0 & NA & NA & 3 & NA & NA \\
\hline \multicolumn{7}{|c|}{ Dominant model } \\
\hline GG & 186 & 1.00 (ref.) & & 198 & 1.00 (ref.) & \\
\hline $\mathrm{GA}+\mathrm{AA}$ & 21 & $1.04(0.53-2.05)$ & 0.91 & 24 & $1.12(0.59-2.16)$ & 0.74 \\
\hline \multicolumn{7}{|l|}{ Allele } \\
\hline G & 393 & 1.00 (ref.) & & 420 & 1.00 (ref.) & \\
\hline A & 21 & $1.04(0.54-2.01)$ & 0.91 & 24 & $1.11(0.59-2.11)$ & 0.75 \\
\hline \multicolumn{7}{|c|}{ ESR2 rs4986938 } \\
\hline \multicolumn{7}{|c|}{ Codominant model } \\
\hline GG & 87 & 1.00 (ref.) & & 107 & 1.00 (ref.) & \\
\hline GA & 99 & $1.30(0.85-1.98)$ & 0.22 & 90 & $0.96(0.63-1.46)$ & 0.85 \\
\hline AA & 21 & $1.12(0.56-2.25)$ & 0.75 & 21 & $0.910 .46-1.82)$ & 0.78 \\
\hline \multicolumn{7}{|c|}{ Dominant model } \\
\hline GG & 87 & 1.00 (ref.) & & 107 & 1.00 (ref.) & \\
\hline $\mathrm{GA}+\mathrm{AA}$ & 120 & $1.26(0.85-1.89)$ & 0.25 & 111 & $0.95(0.64-1.41)$ & 0.80 \\
\hline \multicolumn{7}{|c|}{ Recessive model } \\
\hline $\mathrm{GG}+\mathrm{GA}$ & 186 & 1.00 (ref.) & & 197 & 1.00 (ref.) & \\
\hline $\mathrm{AA}$ & 21 & $0.98(0.51-1.91)$ & 0.95 & 21 & $0.93(0.48-1.80)$ & 0.82 \\
\hline \multicolumn{7}{|l|}{ Allele } \\
\hline $\mathrm{G}$ & 273 & 1.00 (ref.) & & 304 & 1.00 (ref.) & \\
\hline A & 141 & $1.14(0.84-1.53)$ & 0.41 & 132 & $0.96(0.71-1.29)$ & 0.77 \\
\hline
\end{tabular}

rs3020449 (52,53). On the other hand, Dai et al (29) described an association between rs3020449 and increased risk of breast cancer, as well as with tumor size and histological grade.

There are no published studies revealing an association between the rs 3020449 polymorphism and prostate cancer risk; however, there are studies describing an association between other promoter polymorphisms in ESR2 and prostate cancer. The National Cancer Institute's Breast and Prostate Cancer Cohort Consortium study reported an overall increased risk in prostate cancer and advanced stage with the rs3020450 (45). This polymorphism was found to be in complete linkage disequilibrium with rs2987983, which authors of a Swedish study found to be associated with prostate cancer risk and 
suggested that the genetic variation in the promoter region of ESR2 may play a part in the etiology of prostate cancer (54). Holt et al (42) reported an association between the rs1952586 polymorphism and the risk for higher Gleason score tumors.

In summary, the rs3020449 polymorphism in the ESR2 gene markedly contributed to a higher prostate cancer risk in the Slovak population. Analysis of this polymorphism could also provide information regarding the prognosis of the disease, as it was significantly associated with the development of high-grade carcinomas (Gleason score $>7$ ) and tumors with pT3/pT4. The significance of the presented study underlines the fact that the rs3020449 was not found to be in linkage disequilibrium with polymorphisms previously studied with prostate cancer (26). Therefore, it is not likely that the association found in the present study was due to linkage of rs3020449 with previously reported polymorphisms. The functional impact of this polymorphism on the ESR2 gene is still unknown. Analysis of relative ESR2 mRNA expression levels revealed that patients with the rs3020449 GG genotype had tendency to have lower ESR2 expression levels compared with those with the AA genotype. There might also be considerable differences in the genotype frequencies between populations, therefore the results are valid for Slovak and related populations; however, confirmation is required for populations with a different ethnic origin.

\section{Acknowledgements}

Not applicable.

\section{Funding}

This publication is the result of the project implementation: 'Center Of Excellence For Research In Personalized Therapy', ITMS: 26220120053 and VEGA grants (grant nos. 1/0172/18 and 1/0271/19) and APVV-15-0181.

\section{Availability of data and materials}

All data generated or analyzed during this study are included in this published article.

\section{Author's contributions}

JJ, MKS, HD, MH, DE, JK and DD contributed to the study conception and design. Material preparation and data collection were performed by JK, DE and MH. Analysis was performed by JJ, MKS and HD. The first draft of the manuscript was written by $\mathrm{JJ}$ and all authors commented on previous versions of the manuscript. JJ, DD and MKS confirmed the authenticity of all raw data. All authors read and approved the final manuscript.

\section{Ethics approval and consent to participate}

The present study was approved by the Ethics Committee of Comenius University in Bratislava, Jessenius Faculty of Medicine in Martin, Slovakia (approval number: EK 43/2018) and was performed in accordance with ethical standards as laid down in the 1964 Declaration of Helsinki and its later amendments. Informed consent was obtained from all individual participants included in the study.

\section{Patient consent to publication}

Not applicable.

\section{Competing interests}

The authors declare that they have no competing interests.

\section{References}

1. Vrdoljak E, Wojtukiewicz MZ, Pienkowski T, Bodoky G, Berzinec P, Finek J, Todorović V, Borojević N and Croitoru A; South eastern European Research Oncology Group: Cancer epidemiology in central, south and eastern European countries. Croat Med J 52: 478-487, 2011.

2. Gann PH: Risk factors for prostate cancer. Rev Urol 4 (Suppl 5): S3-S10, 2002.

3. Carruba G: Estrogens and mechanisms of prostate cancer progression. Ann NY Acad Sci 1089: 201-217, 2006.

4. Rohrmann S, Platz EA, Selvin E, Shiels MS, Joshu CE, Menke A, Feinleib M, Basaria S, Rifai N, Dobs AS, et al: The prevalence of low sex steroid hormone concentrations in men in the third national health and nutrition examination survey (NHANES III). Clin Endocrinol (Oxf) 75: 232-239, 2011.

5. Bonkhoff $\mathrm{H}$ : Estrogen receptor signaling in prostate cancer: Implications for carcinogenesis and tumor progression. Prostate 78: 2-10, 2018.

6. Yao S, Till C, Kristal AR, Goodman PJ, Hsing AW, Tangen CM, Platz EA, Stanczyk FZ, Reichardt JK, Tang L, et al: Serum estrogen levels and prostate cancer risk in the prostate cancer prevention trial: A nested case-control study. Cancer Causes Control 22: 1121-1131, 2011.

7. Tsai CJ, Cohn BA, Cirillo PM, Feldman D, Stanczyk FZ and Whittemore AS: Sex steroid hormones in young manhood and the risk of subsequent prostate cancer: A longitudinal study in African-Americans and caucasians (United States). Cancer Causes Control 17: 1237-1244, 2006.

8. Barba M, Yang L, Schünemann HJ, Sperati F, Grioni S, Stranges S, Westerlind KC, Blandino G, Gallucci M, Lauria R, et al: Urinary estrogen metabolites and prostate cancer: A case-control study and meta-analysis. J Exp Clin Cancer Res 28: 135, 2009.

9. Parker MG: Structure and function of estrogen receptors. Vitam Horm 51: 267-287, 1995.

10. Levin ER and Hammes SR: Nuclear receptors outside the nucleus: Extranuclear signaling by steroid receptors. Nat Rev Mol Cell Biol 17: 783-797, 2016.

11. Bonkhoff $\mathrm{H}$ and Berges R: The evolving role of oestrogens and their receptors in the development and progression of prostate cancer. Eur Urol 55: 533-542, 2009.

12. Cheng J, Lee EJ, Madison LD and Lazennec G: Expression of estrogen receptor beta in prostate carcinoma cells inhibits invasion and proliferation and triggers apoptosis. FEBS Lett 566: 169-72, 2004.

13. Ellem SJ and Risbridger GP: The dual, opposing roles of estrogen in the prostate. Ann NY Acad Sci 1155: 174-186, 2009.

14. Omoto $\mathrm{Y}$ and Iwase $\mathrm{H}$ : Clinical significance of estrogen receptor $\beta$ in breast and prostate cancer from biological aspects. Cancer Sci 106: 337-343, 2015.

15. Enmark E, Pelto-Huikko M, Grandien K, Lagercrantz S, Lagercrantz J, Fried G, Nordenskjöld $M$ and Gustafsson JA: Human estrogen receptor beta-gene structure, chromosomal localization, and expression pattern. J Clin Endocrinol Metab 82: 4258-4265, 1997

16. Christoforou P, Christopoulos PF and Koutsilieris M: The role of estrogen receptor $\beta$ in prostate cancer. Mol Med 20: 427-434, 2014.

17. Zhu X, Leav I, Leung YK, Wu M, Liu Q, Gao Y, McNeal JE and Ho SM: Dynamic regulation of estrogen receptor-beta expression by DNA methylation during prostate cancer development and metastasis. Am J Pathol 164: 2003-2012, 2004.

18. Rosenkranz K, Hinney A, Ziegler A, Hermann H, Fichter M, Mayer H, Siegfried W, Young JK, Remschmidt $\mathrm{H}$ and Hebebrand J: Systematic mutation screening of the estrogen receptor beta gene in probands of different weight extremes: Identification of several genetic variants. J Clin Endocrinol Metab 12: 4524-4527, 1998. 
19. Fu C, Dong WQ, Wang A and Qiu G: The influence of ESR1 rs9340799 and ESR2 rs1256049 polymorphisms on prostate cancer risk. Tumour Biol 35: 8319-8328, 2014.

20. Putnik M, Zhao C, Gustafsson JA and Dahlman-Wright K: Effects of two common polymorphisms in the 3'untranslated regions of estrogen receptor beta on mRNA stability and translatability. BMC Genet 10: 55, 2009.

21. Barrett LW, Fletcher S and Wilton SD: Regulation of eukaryotic gene expression by the untranslated gene regions and other non-coding elements. Cell Mol Life Sci 69: 3613-2634, 2012

22. Yu KD, Rao NY, Chen AX, Fan L, Yang C and Shao ZM: A systematic review of the relationship between polymorphic sites in the estrogen receptor-beta (ESR2) gene and breast cancer risk. Breast Cancer Res Treat 126: 37-45, 2011.

23. Rezende LM, Marson FA, Lima CS and Bertuzzo CS: Variants of estrogen receptor alpha and beta genes modify the severity of sporadic breast cancer. Gene 608: 73-78, 2017.

24. Lu X, Yamano Y, Takahashi H, Koda M, Fujiwara Y, Hisada A, Miyazaki W and Katoh T: Associations between estrogen receptor genetic polymorphisms, smoking status, and prostate cancer risk: A case-control study in Japanese men. Environ Health Prev Med 20: 332-337, 2015.

25. Li Z, Yang X, Zhang R, Zhang D, Li B, Zhang D, Li O and Xiong Y: No association between estrogen receptor-B Rs4986938 and cancer risk: A systematic review and meta-analysis. Iran J Public Health 48: 784-795, 2019.

26. Bharathi $\mathrm{C}$, Anupama D, Pratibha $\mathrm{N}$ and Venkateshwari A: Impact of genetic variants in estrogen receptor- $\beta$ gene in the etiology of uterine leiomyomas. J Reprod Infertil 20: 151-160, 2019.

27. Lattrich C, Häring J, Schüler S, Skrzypczak M, Ortmann O and Treeck O: Polymorphisms in the promoter region of estrogen receptor $\beta$ gene in endometrial cancer. Arch Gynecol Obstet 289: 631-635, 2014

28. Schüler S, Lattrich C, Skrzypczak M, Fehm T, Ortmann O and Treeck O: Polymorphisms in the promoter region of ESR2 gene and susceptibility to ovarian cancer. Gene 546: 283-287, 2014.

29. Dai Z, Tian T, Wang M, Yang T, Li H, Lin S, Hao Q, Xu P, Deng Y, Zhou L, et al: Genetic polymorphisms of estrogen receptor genes are associated with breast cancer susceptibility in Chinese women. Cancer Cell Int 19: 11, 2019.

30. Ye S, Dhillon S, Ke X, Collins AR and Day IN: An efficient procedure for genotyping single nucleotide polymorphisms. Nucleic Acids Res 29: E88-E88, 2001.

31. Livak KJ and Schmittgen TD: Analysis of relative gene expression data using real-time quantitative PCR and the 2-(Delta Delta C(T)) method. Methods 25: 402-408, 2001.

32. Horvath LG, Henshall SM, Lee CS, Head DR, Quinn DI, Makela S, Delprado W, Golovsky D, Brenner PC, O'Neill G, et al: Frequent loss of estrogen receptor-beta expression in prostate cancer. Cancer Res 61: 5331-5335, 2001

33. Gabal SM, Habib FM, Helmy DO and Ibrahim MF: Expression of estrogen receptor-B (ER-B) in benign and malignant prostatic epithelial cells and its correlation with the clinico-pathological features. J Egypt Natl Canc Inst 19: 239-248, 2007.

34. Latil A, Bieche I, Vidaud D, Lidereau R, Berthon P, Cussenot O and Vidaud M: Evaluation of androgen, estrogen (ER alpha and ER beta), progesterone receptor expression inhuman prostate cancer by real-time quantitative reverse transcription-polymerase chain reaction assays. Cancer Res 61: 1919-1926, 2001.

35. Pasquali D, Staibano S, Prezioso D, Franco R, Esposito D, Notaro A, De Rosa G, Bellastella A and Sinisi AA: Estrogen receptor beta expression in human prostate tissue. Mol Cell Endocrinol 178: 47-50,2001.

36. Leung YK, Lam HM, Wu S, Song D, Levin L, Cheng L, Wu CL and Ho SM: Estrogen receptor beta 2 and beta5 are associated with poor prognosis in prostate cancer, and promote cancer cell migration and invasion. Endocr Relat Cancer 17: 675-689, 2010.

37. Zellweger T, Stürm S, Rey S, Zlobec I, Gsponer JR, Rentsch CA, Terracciano LM, Bachmann A, Bubendorf L and Ruiz C: Estrogen receptor $\beta$ expression and androgen receptor phosphorylation correlate with a poor clinical outcome in hormone-naive prostate cancer and are elevated in castration-resistant disease. Endocr Relat Cancer 20: 403-413, 2013.

38. Grindstad T, Skjefstad K, Andersen S, Ness N, Nordby Y,Al-Saad S, Fismen S, Donnem T, Khanehkenari MR, Busund LT, et al: Estrogen receptors $\alpha$ and $\beta$ and aromatase as independent predictors for prostate cancer outcome. Sci Rep 6: 33114, 2016.
39. Dey P, Jonsson P, Hartman J, Williams C, Ström A and Gustafsson JÅ: Estrogen receptors $\beta 1$ and $\beta 2$ have opposing roles in regulating proliferation and bone metastasis genes in the prostate cancer cell line PC3. Mol Endocrinol 26: 1991-2003, 2012.

40. Cunningham JM, Hebbring SJ, McDonnell SK, Cicek MS, Christensen GB, Wang L, Jacobsen SJ, Cerhan JR, Blute ML, Schaid DJ and Thibodeau SN: Evaluation of genetic variations in the androgen and estrogen metabolic pathways as risk factors for sporadic and familial prostate cancer. Cancer Epidemiol Biomarkers Prev 16: 969-978. 2007.

41. Nicolaiew N, Cancel-Tassin G, Azzouzi AR, Le Grand B, Mangin P, Cormier L, Fournier G, Giordanella JP, Pouchard M, Escary JL, et al: Association between estrogen and androgen receptor genes and prostate cancer risk. Eur J Endocrinol 160: 101-106, 2009.

42. Holt SK, Kwon EM, Fu R, Kolb S, Feng Z, Ostrander EA and Stanford JL: Association of variants in estrogen-related pathway genes with prostate cancer risk. Prostate 73: 1-10, 2013.

43. Robles-Fernandez I, Martinez-Gonzalez LJ, Pascual-Geler M, Cozar JM, Puche-Sanz I, Serrano MJ, Lorente JA and Alvarez-Cubero MJ: Association between polymorphisms in sex hormones synthesis and metabolism and prostate cancer aggressiveness. PLoS One 12: e0185447, 2017.

44. Tang L, Platek ME, Yao S, Till C, Goodman PJ, Tangen CM, Wu Y, Platz EA, Neuhouser ML, Stanczyk FZ, et al: Associations between polymorphisms in genes related to estrogen metabolism and function and prostate cancer risk: Results from the prostate cancer prevention trial. Carcinogenesis 39: 125-133, 2018.

45. Chen YC, Kraft P, Bretsky P, Ketkar S, Hunter DJ, Albanes D, Altshuler D, Andriole G, Berg CD, Boeing H, et al: Sequence variants of estrogen receptor beta and risk of prostate cancer in the national cancer institute breast and prostate cancer cohort consortium. Cancer Epidemiol Biomarkers Prev 16: 1973-1981, 2007.

46. Chae YK, Huang HY, Strickland P, Hoffman SC and Helzlsouer K: Genetic polymorphisms of estrogen receptors alpha and beta and the risk of developing prostate cancer. PLoS One 4: e6523, 2009.

47. Sun T, Lee GS, Werner L, Pomerantz M, Oh WK, Kantoff PW and Freedman ML: Inherited variations in AR, ESR1, and ESR2 genes are not associated with prostate cancer aggressiveness or with efficacy of androgen deprivation therapy. Cancer Epidemiol Biomarkers Prev 19: 1871-1878, 2010.

48. Safarinejad MR, Safarinejad S, Shafiei N and Safarinejad S: Estrogen receptors alpha (rs2234693 and rs9340799), and beta (rs4986938 and rs1256049) genes polymorphism in prostate cancer: Evidence for association with risk and histopathological tumor characteristics in Iranian men. Mol Carcinog 51: E104-E117, 2012

49. Balistreri CR, Caruso C, Carruba G, Miceli V and Candore G: Genotyping of sex hormone-related pathways in benign and malignant human prostate tissues: Data of a preliminary study. OMICS 15: 369-374, 2011.

50. Hoogendoorn B, Coleman SL, Guy CA, Smith K, Bowen T, Buckland PR and O'Donovan MC: Functional analysis of human promoter polymorphisms. Hum Mol Genet 12: 2249-2254, 2003.

51. Fischer C, Juhasz-Boess I, Lattrich C, Ortmann O and Treeck O: Estrogen receptor beta gene polymorphisms and susceptibility to uterine fibroids. Gynecol Endocrinol 26: 4-9, 2010.

52. Treeck O, Elemenler E, Kriener C, Horn F, Springwald A, Hartmann A and Ortmann O: Polymorphisms in the promoter region of ESR2 gene and breast cancer susceptibility. J Steroid Biochem Mol Biol 114: 207-211, 2009.

53. Chen L, Liang Y, Qiu J, Zhang L, Chen X, Luo X and Jiang J: Significance of rs1271572 in the estrogen receptor beta gene promoter and its correlation with breast cancer in a southwestern Chinese population. J Biomed Sci 20: 32, 2013

54. Thellenberg-Karlsson C, Lindström S, Malmer B, Wiklund F, Augustsson-Bälter K, Adami HO, Stattin P, Nilsson M, Dahlman-Wright K, Gustafsson JA and Grönberg H: Estrogen receptor beta polymorphism is associated with prostate cancer risk. Clin Cancer Res 12: 1936-1941, 2006.

This work is licensed under a Creative Commons Attribution-NonCommercial-NoDerivatives 4.0 International (CC BY-NC-ND 4.0) License. 